UDC 542.06:547.792.3:615.243

DOI: 10.15587/2519-4852.2018.128885

\title{
SCALING OF THE PROSPECTIVE ANTI-ULCER API SYNTHESIS
}

\author{
(C) N. Saidov
}

\begin{abstract}
Мета роботи: масштабування лабораторної методики синтезу 4-метоксіаніліду 5-(4-метилфеніламінометил-4-(2-метилфеніл)-1,2,4-триазол-4H-3-ілтіооцтової кислоти (Тріазопразола) для відтворення в промислових умовах.

Методи. При розробиі промислової технології оцінювали ефективність синтезу (виходи на кожній стадії синтезу, можливість проведення синтезу без виділення напівпродуктів), відповідність принципам зеленої хімії та економічну доцільність. Відповідно до конщепџіï Quality by design, принципами зеленої хімї $і$ розробленими раніме алгоритмами для оптимізації промислового синтезу проаналізовано теоретичні можливості проведення синтезу в промислових умовах. Оптимальні умови проведення реакиій визначені експериментально.
\end{abstract}

Результати. В результаті проведених експериментальних досліджень доведено можливість синтезу ключового інтермедіату - 5-метилфеніламінометил-4-(2-метилфеніл)-1,2,4-триазол-3-тіону - без виділення проміжного продукту, щзо дозволило збільиити його вихід в перерахунку на вихідні речовини . Скорочено час проведення окремих стадій синтезу, при изьому вихід і чистота продуктів залишається задовільною. Для алкілування ключового інтермедіату оптимальними умовами обрані температура реакиії - $70{ }^{\circ} \mathrm{C}$, час - 1 година, використання системи ДМФА-луг. Такі умови дозволяють забезпечити високий вихід $і$ чистоту кінцевого продукту.

Висновки Здійснено масштабування методики синтезу потенційного АФІ з противиразковою дією 4метоксіаніліда 5- (4-метілфеніламінометіл-4-(2-метилфеніл)-1,2,4-триазол-4Н-3-ілтіооцтової кислоти для відтворення в умовах промислового виробництва з використанням концепиії Quality by design ma приниипів «зеленої хімії». Скорочено кількість стадій синтезу. Підібрано умови, в яких иільовий продукт утворюється з максимальним виходом і прийнятною чистотою

Ключові слова: активний фармацевтичний інгредієнт, промисловий синтез, масштабування, зелена хімія, похідні 1,2,4-триазолу, противиразкові засоби

\section{Introduction}

1,2,4-Triazoles are substances that have begun to be widely introduced into pharmaceutical practice in recent times. Among them, substances that have different types of pharmacological activity were found. The most famous of them are Ukrainian brand thiotriazoline [1,2], ribavirin, thiamazole, fluconazole, itraconazole and others [3]. The attractiveness of this class of compounds is also due to the fact that the synthesis of the starting materials is fairly simple and allows the introduction of various substituents into the free positions of the heterocyclic ring during the cyclization stage.

2. Formation of the problem in a general way, the relevance of the theme and its connection with important scientific and practical issues

We previously planned and carried out the synthesis of biologically active substances in the series of aryl (alkyl) amides of 4,5-disubstituted 1,2,4-triazol-4H-3ylthioacetic acids $[4,5]$. Among the compounds synthesized substances with a high level of antiulcer, anticonvulsant and antitumor activity were found $[4,6]$. The most active substances were patented. At present, some of them are included into the research plans of some pharmaceutical enterprises in Ukraine and Tajikistan.

To conduct in-depth studies on preclinical research, as well as pharmaceutical development, it is necessary to scale-up the laboratory synthesis procedure and develop an industrial technology for the synthesis of a potential APIs.
3. Analysis of recent studies and publications in which a solution of the problem is described and to which author refers

Earlier, scientists of the National Pharmaceutical University proposed approaches to this kind of development [7]. Based on this, we took into account that the peculiarity of the synthesis of API in industrial conditions is the need to ensure not only high yields of the final product, but also acceptable purity within the requirements of the European Pharmacopoeia. For this, it is necessary to minimize the number of synthesis steps, to develop an optimal procedure for purification from starting materials and intermediates, and to prevent the occurrence of side processes. In addition, we have tried to take into account the principles of "green chemistry" to ensure safe production for personnel and the environment.

\section{The field of research considering the general} problem, which is described in the article

Based on the results of the pharmacological screening, a prospective anti-ulcer API-4-methoxyanilide of 5-(4-methylphenylaminomethyl)-4-(2-methylphenyl)1,2,4-triazol-4H-3-ylthioacetic acid (1) with high level of activity in the screening experiment was identified [5]:<smiles>COc1ccc(NC(=O)CSc2nnc(CNc3ccc(C)cc3)n2-c2ccccc2C)cc1</smiles> 
This compound was planned for in-depth preclinical studies and the pharmaceutical development of a dosage form under the conventional name Triazoprazole.

\section{Formulation of goals (tasks) of article}

The aim of this study is to scale-up the laboratory procedure for the synthesis of 4-methoxyanilide 5-(4methylphenylaminomethyl)-4-(2-methylphenyl)-1,2,4triazol-4H-3-ylthioacetic acid (Triazoprazole) for reproducing and operating in industrial conditions.

\section{Presenation of the main research material} (methods and objects) with the justification of the results

Under laboratory conditions, the synthesis of this substance was carried out in three stages:

Synthesis of 5-(4-methylphenylaminomethyl)-4(2-methylphenyl)-1,2,4-triazol-3-thione (intermediate 1);

Synthesis of 4-methoxyphenylamide of chloroacetic acid (intermediate 2);

Interaction of intermediates 1,2 lead to the endproduct 4-methoxyanilide of 5- (4-methylphenylaminomethyl)-4-(2-methylphenyl)-1,2,4-triazol-4H-3-ylthioacetic acid [5].

Based on the analysis of literature data [8-10], this method that is an optimal and perhaps the only possible for the formation of a 1,2,4-triazole ring containing a thiol group in the $3^{\text {rd }}$ position, 2-methylphenyl moiety in $4^{\text {th }}$ position and a 4-methylphenylaminomethylene fragment in $5^{\text {th }}$.

Scheme synthesis of the potential API is fairly simple, does not require special synthetic techniques and using of toxic solvents. We carried out a preliminary evaluation of pharmaceutical development using the method proposed by the scientists of the National University of Pharmacy [7, 11].

When developing the industrial technology, we took into account several different factors: the efficiency of the synthesis (the yields at each stage of the synthesis, the possibility of carrying out the synthesis without separating the intermediates). We also studied correspondence to the green chemistry principles [12], the possibility of obtaining synthetic intermediates from the chemical manufacturers and the economic feasibility. In accordance with the algorithm proposed earlier Pharmaceutical development of industrial synthesis of APIs should be given priority to the acquisition of reagents, and not to their synthesis. Important was also a comparison of the toxic properties of the starting materials.

In accordance with the Quality by design concept and the algorithms developed earlier [7, 11], the first stage to optimize industrial synthesis was analysis of the theoretical possibilities for carrying out of chemical reactions. For implementation into industrial production, we considered each stage separately.

According to the synthesis scheme (Fig. 1) 4-toluidine (2) is used as the starting substance to prepare the intermediate 1 , which is alkylated with chloroacetic acid ethyl ester. The resulting 4-methylphenylaminoacetic acid ethyl ester (3) is converted into hydrazide (4) by the action of hydrazine hydrate.

When the hydrazide reacts with 2-methylphenyl isothiocyanate (5), an appropriate thiosemicarbazide (6) is formed, the cyclization of which leads to the key intermediate (7) usually existing in two tautomeric forms.<smiles>CCOC(=O)CNc1ccc(C)cc1</smiles>

2<smiles>Cc1ccc(NCC(=O)NN)cc1</smiles>

4<smiles>Cc1ccc(NCc2nnc(S)n2-c2ccccc2C)cc1</smiles><smiles>CC#CC</smiles><smiles>CCCc1ccc(NCC(=O)NNC(=S)Nc2ccccc2C)cc1</smiles>

6<smiles>Cc1ccccc1-n1c(CNc2ccccc2)n[nH]c1=S</smiles>

7

Fig. 1. Scheme of the synthesis of 5-(4-methylphenylaminomethyl)-4-(2-methylphenyl)-1,2,4-triazol-3-thione (step 1) 
We analyzed the list of possible reagents for synthesis at this stage. Thus, to obtain hydrazides with high yields, the interaction of hydrazine hydrate with esters is an optimal [13]. These reactions proceed easily and are characterized by high yields even without heating. The use of acids as starting substance in this case is impossible, and the use of acid chloranhydrides can lead to the production of a symmetric hydrazides. Therefore, the use of chloroacetic acid ethyl ester as a starting material in the reaction is theoretically justified and does not require additional experimental justification. It should be noted that $p$-toluidine, like most anilines, is toxic and its use in the company requires certain protective measures for personnel [14].

The following issues were subject to discussion:

- Commercial availability of intermediates - 2-(4methylphenyl)aminoacetic acid hydrazide, 2-methylphenyl isothiocyanate. In the absence of those, the optimal acylating agent for the synthesis of hydrazide and, accordingly, the starting material for the alkylation of aniline in the $1^{\text {st }}$ stage.

- Solvent in the alkylation step and optimum process conditions

- Optimal conditions for obtaining hydrazide depending on the choice of the starting material at the $1^{\text {st }}$ stage.

- Conditions for obtaining thiosemicarbazide 6 . Optimal cyclization conditions for the production of triazole 7.

- Possibility of one pot synthesis without separation of intermediate products. Prevention of impurities formation.

4-Methylphenylaminoacetylhydrazide (4) is present on the market of chemical substances. This allows to reduce the first two stages - synthesis of ethyl 4methoxyphenylaminoacetate and its hydrazinolysis. The substances are offered by the Ukrainian (Enamin and Orgsintez), American (Ryan Scientific, Inc), Spanish (Santa Cruz Biotechnology), as well as Chinese (Hangzhou J \& H Chemical Co., Ltd) and many other international manufacturers and implementers. Therefore, it is expedient to purchase this intermediate product instead of two stages of synthesis at the enterprise. In addition, this avoids the use of toxic toluidine 2 during production.

Thus, the synthesis of the first key intermediate, 5-(4-methylphenylaminomethyl)-4-(2-methylphenyl)-

1,2,4-triazole-3-thione 7, is supposed to be carried out in two stages - the interaction of 4-methylphenylaminoacetyl hydrazide with 2-methylphenyl isothiocyanate and subsequent cyclization of the thiosemicarbazide 6 into correspondent triazole 7. As a result of the experimental study, it was found that in the first stage, after 1 hour of the reaction mass boiling, impurities of the initial substances still remain in it, while after 1.5 hours a chromatographic plate only spot thiosemicarbazide is observed and there no spot of the starting materials. Therefore, we extended the stage of interaction of hydrazide with thiosemicarbazide up to 1.5 hours (Table 1).

In laboratory synthesis, we isolated the thiosemicarbazide formed from the reaction mixture [5]. The high yield of thiosemicarbazide and the absence of possible side reactions, as well as the absence of a significant amount of impurities of the starting materials, became a prerequisite for the possibility of carrying out the synthesis without isolation of the intermediate thiosemicarbazide.

Previously, it was necessary to establish the optimal time for cyclization of thiosemicarbazide into the key triazole thione 7. Evaluation of the completeness of the synthesis was carried out by the yield of the key intermediate, and the purity of the resulting intermediate by the TLC method (Table 2).

Table 1

The effect of solvent and temperature on yield and purity of the thiosemicarbazide 6

\begin{tabular}{|c|c|c|c|c|}
\hline & Solvent & Time, $\min$ & Yield, $\%$ & Impurities (TLC)* \\
\hline 1 & \multirow[t]{4}{*}{ ethanol } & 60 & 55 & +++ \\
\hline 2 & & 70 & 64 & ++ \\
\hline 3 & & 80 & 67 & + \\
\hline 4 & & 90 & 81 & $* *$ \\
\hline 5 & \multirow[t]{4}{*}{ methanol } & 60 & 57 & +++ \\
\hline 6 & & 70 & 64 & ++ \\
\hline 7 & & 80 & 68 & + \\
\hline 8 & & 90 & 82 & $-* *$ \\
\hline 9 & \multirow[t]{4}{*}{ acetonitrile } & 60 & 57 & +++ \\
\hline 10 & & 70 & 65 & ++ \\
\hline 11 & & 80 & 67 & + \\
\hline 12 & & 90 & 84 & -** \\
\hline
\end{tabular}

Note: * - Visual evaluation of the spot fluorescence intensity in UV light; ** - On the chromatographic plate, traces at the level of the spots of starting materials

Table 2

The effect of the time on the 5-(4-methylphenylaminomethyl)-4-(2-methylphenyl)-1,2,4-triazole-3-thione yield

\begin{tabular}{|c|c|c|c|c|c|c|c|}
\hline & Time & Yield, $\%$ & Impurities* & & Time & Yield, \% & Impurities* \\
\hline 1 & 210 & 59 & ++ & 4 & 300 & 76 & + \\
\hline 2 & 240 & 68 & ++ & 5 & 330 & 78 & + \\
\hline 3 & 270 & 75 & + & 6 & 360 & 78 & + \\
\hline
\end{tabular}

Note: *-Visual evaluation of the spot fluorescence intensity in UV light 
Experimental studies have established that satisfactory yield and purity of key intermediate can be achieved after 270 minutes of synthesis. Further, the yield grows insignificantly. Therefore, it was decided to shorten the synthesis time at this stage to 4.5 hours instead of 5, during which the synthesis was previously performed in laboratory synthesis [5].

To carry out the synthesis without isolation of thiosemicarbazide, after completion of the first stage of the synthesis, distillation of ethyl alcohol under vacuum was carried out. To the wet, dry residue, after distilling off the alcohol, water was added and the precipitate was suspended, and then alkali was added for cyclization. As shown by the results of the experiment, the yield of 5-(4methylphenylaminomethyl)-4-(2-methylphenyl)-1,2,4triazole-3-thione in terms of the initial hydrazide was expected to be greater (72\% vs. $61 \%$ ) as result of onepot synthesis due to the absence of losses, which are unavoidable during thiosemicarbazide isolation. The purity of the product was comparable at the same time.

Synthesis procedures

Method 1 - with the isolation of thiosemicarbazide. $1^{\text {st }}$ stage. $149.2 \mathrm{~g}(1 \mathrm{Mol})$ of 4-methylphenyl isothiocyanate are slowly added dropwise to a solution of $199.6 \mathrm{~g}$ (1 Mol) of 4-methylphenylaminoacetylhydrazide 3 in $1 \mathrm{~L}$ of ethanol with vigorous stirring. The reaction mixture was heated under reflux for 1.5 hours, cooled. The precipitate of the substituted thiosemicarbazide is filtered off and dried. Yield $266 \mathrm{~g}(81 \%) .2^{\text {nd }}$ stage. To a suspension of $266 \mathrm{~g}(0.81 \mathrm{Mol})$ of thiosemicarbazide 6 in 1 liter of water, $90.7 \mathrm{~g}(1.62 \mathrm{Mol})$ of potassium hydroxide was added. The reaction mixture was refluxed for 4.5 hours. After cooling, the mixture is acidified with hydrochloric acid to $\mathrm{pH} 3-4$. The precipitate of 5-(4methoxyphenylaminomethyl)-4-(2-methylphenyl)-1,2,4triazol-4H-3-thione is filtered off, washed with water and dried. The yield is $180.1 \mathrm{~g}$ (75\%, recalculating to the original hydrazide $60.8 \%$ ).
Method 2 - without isolation of thiosemicarbazide. $149.2 \mathrm{~g}(1 \mathrm{Mol})$ of 2-methylphenyl isothiocyanate are slowly added to a solution of $199.6 \mathrm{~g}$ (1 Mol) of 4methylphenylaminoacetylhydrazide 3 in $1 \mathrm{~L}$ of ethanol with vigorous stirring. The reaction mixture was heated under reflux for 1.5 hours, cooled, alcohol $(700 \mathrm{ml})$. was distilled under vacuum. 1 liter of water is added to the residue in the flask with stirring, the suspension is stirred for 10 minutes, then, while stirring is continued, $112 \mathrm{~g}$ ( $2 \mathrm{~mol}$ ) of potassium hydroxide are gradually added. The reaction mixture was refluxed for 4.5 hours. After the end of reaction, the mixture is cooled, acidified with hydrochloric acid to $\mathrm{pH} 3-4$. The precipitate of the 5-(4methylhenylaminomethyl)-4-(2-methylphenyl)-1,2,4triazol-4H-3-thione is filtered off, washed with water, and dried. Yield: $213.4 \mathrm{~g}(72 \%)$.

The next step in the synthesis is obtaining of the second intermediate, 4-methoxyanilide of chloroacetic acid. This synthesis is quite simple and involves the acylation of 4-methoxyaniline (4-anisidine) with chloroacetyl chloride. The use of chloroacetic acid or its esters for this purpose is irrational, since in this case an alkylation reaction of anisidine will predominantly take place and the main product of the reaction will be the phenylaminoacetic acid derivative. Acid chloride purchase due to its instability and high price is irrational, and its production is associated with the formation of volatile toxic products, which, in addition, can corrode equipment. Therefore, we studied the possibility of buying anilide. Manufacturers and distributors of chemical substances offer 4-methoxyanilide of chloroacetic acid. Its price is high enough. However, taking into account the difficulties described above, coupled with its independent synthesis, we gave priority to its acquisition. Thus, the number of synthesis steps is reduced by one more.

The final step in the synthesis of the aim substance is alkylation. Synthesis of the desired product (1) is carried out by reacting the intermediates 7 and 8 (Fig. 2).

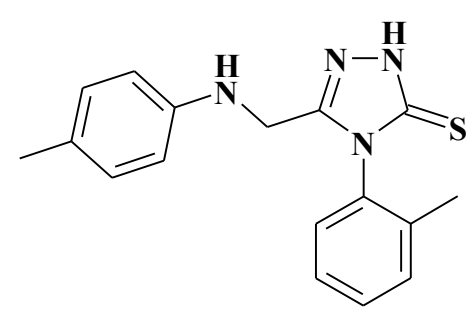

7

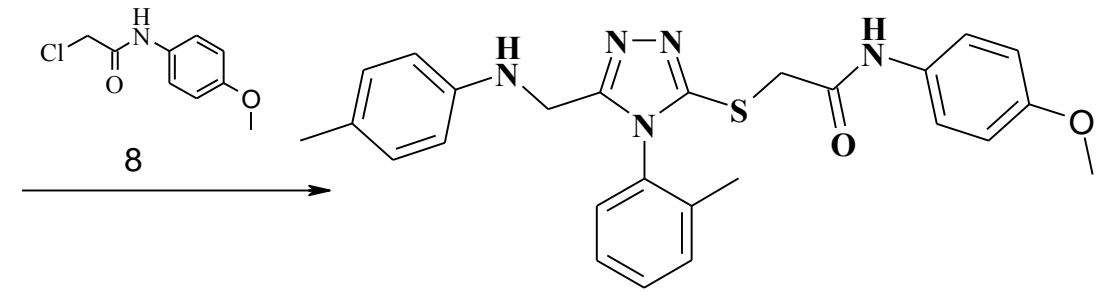

1

Fig. 2. Scheme of the synthesis of 4-methoxyanilide of 5-(4-methylphenylaminomethyl)-4-(2-methylphenyl)-1,2,4triazol-4H-3-ylthioacetic acid.

Alkylation of the triazole-thione is possible due to thion-thiol tautometry, the stabilization of the thiol form occurs in an alkaline medium. Typically, the alkylation is carried out in an alcoholic medium in the presence of various basic catalysts. High yields can be achieved by using for this purpose an alcoholic solution of alkali or a superbasic medium - the DMF-crystalline alkali system or DMSO-potash. Since DMSO is heavily washed from the equipment and can generate toxic sulfur-containing substances under temperature influence, we conducted experimental studies for two systems. The effect of solvents, time and temperature (during DMF using) was studied. As can be seen from Table 3, the best yields were achieved when using for the synthesis in the DMFalkali medium.

We preferred preference for industrial synthesis at $70^{\circ} \mathrm{C}$, that is consistent with the principle of "green chemistry" on saving energy costs. 
Table 3

Effect of synthesis conditions on the yield and purity of the end product

\begin{tabular}{|c|c|c|c|c|c|}
\hline & & Time, min & Temperature & Yield & Impurities* \\
\hline 1 & \multirow{5}{*}{ Alkali solution in alcohol } & 30 & \multirow{5}{*}{ boiling } & 65 & ++ \\
\hline 2 & & 40 & & 71 & ++ \\
\hline 3 & & 50 & & 84 & + \\
\hline 4 & & 60 & & 86 & + \\
\hline 5 & & 70 & & 87 & + \\
\hline 6 & \multirow{8}{*}{ DMF-alkali } & \multirow{2}{*}{30} & $70^{\circ} \mathrm{C}$ & 72 & ++ \\
\hline 7 & & & $120^{\circ} \mathrm{C}$ & 77 & ++ \\
\hline 8 & & \multirow{2}{*}{40} & $70^{\circ} \mathrm{C}$ & 86 & ++ \\
\hline 9 & & & $120^{\circ} \mathrm{C}$ & 88 & ++ \\
\hline 10 & & \multirow{2}{*}{50} & $70^{\circ} \mathrm{C}$ & 92 & + \\
\hline 11 & & & $120^{\circ} \mathrm{C}$ & 94 & ++ \\
\hline 12 & & \multirow{2}{*}{60} & $70^{\circ} \mathrm{C}$ & 93 & + \\
\hline 13 & & & $120^{\circ} \mathrm{C}$ & 94 & ++ \\
\hline
\end{tabular}

Note: * - Visual evaluation of the spot fluorescence intensity in UV light

Procedure of the synthesis of 4-methoxyanilide 5(4-methylphenylaminomethyl)-4-(2-methylphenyl)1,2,4-triazol-4H-3-ylthioacetic acid (1). To a solution of $296.4 \mathrm{~g}(1 \mathrm{Mol})$ of mercaptotriazole 7 in $1000 \mathrm{ml}$ ethanol, $1000 \mathrm{ml}$ of an aqueous solution of $56 \mathrm{~g}$ (1 Mol) of $\mathrm{KOH}$ at stirring $1000 \mathrm{ml}$ of an alcoholic solution of $200 \mathrm{~g}$ (1 Mol) of chloroacetic acid 4-metoxyanilide is added. The reaction mixture is heated at $70^{\circ} \mathrm{C}$ for 1 hour, than cooled, poured out into $3000 \mathrm{ml}$ of water. The precipitate formed is washed with water and dried. Yield 440, $4 \mathrm{~g}$ $(93 \%)$

\section{Conclusion from the conducted research and prospects for further development of this field}

Scaling of the method of synthesis of a potential API with the antiulcer action - 4-methoxyanilide of 5-(4methylphenylaminomethyl)-4-(2-methylphenyl)-1,2,4triazol-4H-3-ylthioacetic acid (Triazoprazol) for industrial production using the concept Quality by design and "green chemistry "was carried out. The number of stages of synthesis has been reduced and the conditions when the end product is formed with the maximum yield and acceptable purity are selected experimentally.

\section{References}

1. Taschuk V. K., Solobiukova N. A., Makarov A. A. Effectiveness of Thiotriazolin in a Complex Treatment of the Patients with Acute Coronary Syndrome without ST Elevation // Emergency medicine. 2017. Issue 8 (79). P. 35-43. doi: 10.22141/22240586.8.79.2016.90371

2. Solobiukova N. A., Makarov A. A., Svishhenko E. P. Metaanaliz effektivnosti i bezopasnosti primeneniya lekarstvennogo sredstva Tiotriazolin ${ }^{\circledR}$ pri stabil'nykh formakh ishemicheskoy bolezni serdtsa // Arterial'naya gipertenziya. 2015. Issue 6 (44). P. 31-37

3. Remington, the science and practice of pharmacy / ed. by Loyd V. A. London-Philadephia: The pharmaceutical Press, 2013. $3056 \mathrm{p}$

4. Synthesis, docking studies, and biological evaluation of anti-ulcer activity of 4-allyl-5-(4-R1)-phenylthiomethyl-1,2,4triazole-3-ylmercaptoacetic acid derivatives / Georgiyants V. et. al. // European Chemical Bulletin. 2014. Vol. 3, Issue 5. P. $466-471$.

5. Synthesis of novel substituted 4-phenyl-5-phenoxymethyl-3-mercapto-1,2,4-triazole $(4 \mathrm{H})$ derivatives as potential antiulcer agents / Perekhoda L. et. al. // Scripta Scientifica Pharmaceutica. 2015. Vol. 2, Issue 2. P. 46-52. doi: 10.14748/ssp.v2i2.1300

6. Screening investigation of novel 1,2,4-triazole-3-thione derivatives on anticonvulsant activity / Kavraiskiy D. P. et. al. // American Journal of pharmacology and phytotherapy. 2016. Vol. 1, Issue 1. P. 10-14.

7. Kushniruk V. M., Severina A. I., Georgiyants V. A. Standardization of the Active Pharmaceutical Ingredients Industrial Synthesis Technology // Acta Chim. Pharm. Indica. 2017. Vol. 7, Issue 2. P. URL: http://www.tsijournals

com/abstract/standardization-of-the-active-pharmaceutical-ingredients-industrial-synthesis-technology-13367.html

8. Design, selective alkylation and X-ray crystal structure determination of dihydro-indolyl-1,2,4-triazole-3-thione and its 3benzylsulfanyl analogue as potent anticancer agents / Boraei A. T. A. et. al. // European Journal of Medicinal Chemistry. 2017. Vol. 125. P. 360-371. doi: 10.1016/j.ejmech.2016.09.046

9. Synthesis and antibacterial activity of some new 4-anilino-5-phenyl-4H-1,2,4-triazole-3-thiol derivatives / Ghattas, A. E.B. A. G. et. al. // Arabian Journal of Chemistry. 2016. Vol. 9. P. 1654-1659. doi: 10.1016/j.arabjc.2012.04.016

10. Synthesis and antimicrobial evaluation of 5-aryl-1,2,4-triazole-3-thione derivatives containing a rhodanine moiety / Li C. et. al. // Bioorganic \& Medicinal Chemistry Letters. 2015. Vol. 25, Issue 15. P. 3052-3056. doi: 10.1016/j.bmcl.2015.04.081

11. Kontseptsiya Quality by design v proizvodstve aktivnikh farmatsevticheskikh ingredientov. 1. Analiz faktorov, vliyayushhikh na kachestvo pri planirovanii proizvodstva (sinteza) substantsii amizona / Georgiyants V. A. et. al. // Vestnik Tadzhikskogo natsional'nogo universiteta. Seriya estestvennykh nauk. 2013. Issue 1/3 (110). P. 81-84.

12. Anastas P. T., Warner J. C. Green Chemistry: Theory and Practice. Oxford University Press: New York, 1998.30 p.

13. Saha A. et. al. Development and assessment of green synthesis of hydrazides // Indian Journal of Chemistry Section B. 2010. Vol. 49B. P. 526-531.

14. European Comission. The classification, labelling and packaging of chemical substances and mixtures. URL: http://ec.europa.eu/environment/chemicals/labelling/history_en.htm

Дата надходження рукопису 22.03.2018

Narzullo Saidov, PhD, Associate Professor, Department of Pharmaceutical Chemistry, Tajik national university Rudaki str., 17, Dushanbe, Tajikistan, 734025 